\title{
THE GABAergic SYSTEM : A POSSIBLE COMPONENT OF ESTROGENIC FEEDBACK ON GONADOTROPIN SECRETION IN RAINBOW TROUT (ONCORHYNCHUS MYKISS).
}

\author{
I. ANGLADE, V. DOUARD, C. LE JOSSIC-CORCOS, E.L. MAÑANOS, D. MAZURAIS, \\ D. MICHEL and O. KAH
}

\author{
Endocrinologie Moléculaire de la Reproduction, CNRS UPRES-A 6026, \\ Campus de Beaulieu, 35042 Rennes Cedex, France.
}

\begin{abstract}
In teleost fish, GTH secretion is controiled by a large number of neuroendocrine factors at the central level and steroid feedback represents an efficient process to synchronize the activity of all the systems involved along the brain-pituitary-gonad axis. Estrogen effects are mediated by specific nuclear receptors that act as transcription factors to regulate the expression of target genes. In order to understand the neuroendocrine mechanisms involved in the estrogen feedback on GTH secretion, we need, as a first step, to know the nature of target cells at the pituitary and central levels. In rainbow trout, some estrogen receptors expressing cells are identified but the nature of a large number of them remains unknown. In this paper, we explain our strategy to identify the central target of estrogen using both in situ hybridization and immunohistochemistry. We focused our attention on GABA neurons of which the distribution, in some central areas, exactly overlaps with that of estrogen receptors expressing cells.
\end{abstract}

\section{LE SYSTÈME GABAergique : UNE ÉVENTUELLE COMPOSANTE DU RÉTROCONTRÔLE STÉROÏDIEN SUR LA SÉCRÉTION DES GONADOTROPHINES CHEZ LA TRUITE ARC-EN-CIEL (ONCORHYNCHUS MYKISS).}

\section{RÉSUMÉ}

Chez les poissons téléostéens, la sécrétion de GTH est contrôlée par un grand nombre de facteurs neuroendocriniens centraux et les rétrocontrôles stéroïdiens représentent un moyen efficace permettant de synchroniser l'activité de ces différents systèmes interagissant le long de l'axe cerveau-hypophyse-gonades. Les effets de l'oestradiol sont médiés par des récepteurs nucléaires spécifiques agissant comme des facteurs de transcription capables de réguler l'expression de gènes cibles. Dans le but de comprendre les mécanismes neuroendocriniens impliqués dans les rétrocontrôles stéroïdiens sur la sécrétion des gonadotrophines, il est important de connaître la nature des cellules exprimant les récepteurs à l'oestradiol au niveau central et hypophysaire. Chez la truite arc-en-ciel, un certain nombre de cellules exprimant les récepteurs à l'oestradiol ont été identifiées. Cependant, la nature d'un grand nombre de cellules RE2-positives demeure, à ce jour, indéterminée. Nous résumons ici notre stratégie afin d'identifier les cellules cibles de l'oestradiol dans le cerveau en utilisant comme moyen d'approche l'hybridation in situ et l'immunohistochimie. Nous avons focalisé notre attention sur les neurones synthétisant l'acide $\gamma$-aminobutyrique (GABA) dont la distribution, dans certaines régions du cerveau, correspond parfaitement à celle des cellules exprimant les récepteurs à l'oestradiol. 


\section{INTRODUCTION}

In fish, it is well established that sex steroids, notably estradiol, modulate GTH release, by action at the pituitary and central levels. Indeed, if a direct effect of estradiol on GTH2 cells has been largely described in several fish, it is also clear that estradiol can influence a large number of neuronal systems involved in the GTH secretion (for review, $\mathrm{KAH}$ et al., 1993 ; TRUDEAU and PETER, 1995).

Modulatory genomic actions of estradiol mainly involve specific nuclear receptors that belong to the superfamily of nuclear hormone receptors including also receptors for thyroid hormones, vitamin D3, retinoic acid and some orphan receptors for which no endogenous ligands are known. All these receptors have a common structure, with an $\mathrm{N}$-terminal DNA-binding domain and a C-terminal hormone-binding domain, and act as ligand-dependent transcription factors. Once activated by the ligand, these receptors are able to bind on consensus sequences located on the promoter of target genes to regulate the transcription of these genes (BEATO et al., 1995). Recently, the obtention of the full length sequence of a rainbow trout estrogen receptor (rtER) cDNA has been a decisive step to obtain new molecular tools (PAKDEL et al., 1990). In particular, it has been possible to detect both rtER mRNA and rtER protein using riboprobes or specific antibodies after overexpression of the hormone-binding domain fused with glutathione S-transferase in E. Coli (PAKDEL et al., 1994). This approach offered the opportunity to localize the neuronal target of estradiol at the central and pituitary levels, permitting to progress in our understanding of the estrogenic feedback mechanisms on GTH synthesis and secretion.

\section{CENTRAL AREAS TARGET OF ESTRADIOL}

Before the cloning of ER, only autoradiographic studies using tritiated estradiol were performed to localize areas concentrating estradiol in the brain of fish (KIM et al., 1978). These studies demonstrated that steroid binding occurred mainly in the ventral telencephalon, the preoptic region, the thalamus and the mediobasal hypothalamus. The availability of new tools to carry out in situ hybridization (ISH ; SALBERT et al., 1991) or immunohistochemistry (IHC ; ANGLADE et al., 1994) in rainbow trout confirmed and precised the results obtained by autoradiography.

In the ventral telencephalon, ER-expressing cells are located at the junction between the ventral and dorsal areas of the ventral telencephalon, in a position just rostral to the anterior commissure (junction $\mathrm{V} v / \mathrm{Vd}$ ). Some cells were also detected in the area ventralis pars supracommissuralis (Vs).

The preoptic region represents a major target of estradiol in rainbow trout since both ISH and IHC showed a very high density of cells expressing both rtER mRNA and rtER protein. The detected cells are consistently observed in the medial and ventral areas around the preoptic recess in a lateral position (NPOpc) and in the ventral wall of the preoptic recess (NPOav). Some positive cells were also located in the magnocellular part of the preoptic nucleus (NPOmc). Another major target of estradiol in the mediobasal hypothalamus is represented by each division of the nucleus lateralis tuberis (NLTa, NLTp, NLTi), except the lateral part (NLTI) where no immunopositive cells were detected. Some positive cells were observed caudally in the nucleus saccus vasculosus (NSV). In the pituitary, estrogen receptors are mainly expressed in the rostral pars distalis (RPD), and in a lesser extent, in the pars intermedia (PI).

These results show that estradiol may exert its actions directly at the pituitary level, but also at the central level by modulating the activity of neuroendocrine systems regulating pituitary functions. Indeed, retrograde transport studies showed that these three regions 
represent the main hypophysiotropic areas in the brain (ANGLADE et al., 1993 ; JOHNSTON and MALER, 1992) of fish.

\section{WHICH CELLULAR TARGET IN THE BRAIN ?}

In teleost fish, gonadotrophin release is mainly controlled by the stimulatory action of GnRH and an inhibitory action of dopamine. However, other central factors are involved in the control of GTH2 (for review, KAH et al., 1993 ; TRUDEAU, 1997) and the success of reproduction depends largely on the synchronization of the activity of all these neuroendocrine systems : estrogenic feedback is an essential mechanism contributing in this synchronization by regulating the transcription of specific genes. Due to the large number of neuronal systems located in estradiol-receptive areas, we have focused our attention on those known to be both strongly involved in GTH2 secretion and regulated by sex steroids (TRUDEAU, 1997 ; KAH et al., 1993). Hence, the second step of our study has been to identify the target cells and possibly the molecular targets of estradiol. Such an approach requires double immunohistochemical staining to characterize the phenotype of rtER-expressing cells. The protocol used was previously detailed in NAVAS et al. (1995) and LINARD et al. (1996b). The principle is based on the detection of two antigenes using two different antibodies.

\section{DOPAMINERGIC NEURONS EXPRESS ESTRADIOL RECEPTORS BUT GNRH NEURONS DO NOT}

In rainbow trout, physiological studies have shown a regulation of the activity of dopaminergic systems by estradiol (SALIGAUT et al., 1992). Indeed, in vivo experiments established that dopaminergic inhibition of GTH2 secretion is modulated by the levels of circulating estradiol (LINARD et al., 1996a). To test the possibility of a direct action of estradiol on dopaminergic neurons, double immunostaining was performed and showed the existence of a subpopulation of dopaminergic neurons that indeed express estradiol receptors (LINARD et al., 1996b). These dopaminergic neurons expressing rtER are restricted to the ventral preoptic region in a nucleus represented by the ventral wall of the preoptic recess and named nucleus preopticus pars anteroventralis. However, a large number of cells expressing rtER in the preoptic region remains to be identified.

Many studies have shown that sex steroid exerts a positive feedback on $\mathrm{GnRH}$ neurons activity. For example, in several species, estrogen causes an increase of $\mathrm{GnRH}$ contents in the brain and the pituitary (DUFOUR et al., 1985, 1993 ; MONTERO et al., 1995 ; TRUDEAU et al., 1991). In addition, it has been demonstrated that the human estrogen receptor binds to an estrogen-responsive-like sequence on the promotor of GnRH gene in salmon (KLUNGLAND et al., 1993). All these data suggest that, in fish, GnRH neurons could represent a direct target of estradiol. However, extensive immunohistochemical studies (NAVAS et al., 1995) failed to demonstrate that GnRH neurons express estradiol receptors, similar to the mammalian situation (SHIVERS et al., 1983 ; HERBISON and THEODOSIS, 1992). Hence, it becomes essential to identify other cellular targets of estradiol in order to understand how estradiol exerts its feedback on GnRH and GTH secretion in fish.

\section{WHICH OTHER POTENTIAL TARGET ?}

In all vertebrates, GABA is considered as the major inhibitory neurotransmitter in the central nervous system. Its implication in many sensorial, behavioral and neuroendocrine functions was largely described. It appears that GABA is strongly involved in the regulation 
of Luteinizing Hormone-Releasing Hormone ( $\mathrm{LH}-\mathrm{RH}$ ) and Luteinizing Hormone (LH) (DONOSO et al., 1994). Most of studies report an inhibitory action of GABA on gonadotropin release, probably mediated mainly at the central level, through an action on the LH-RH neuronal system (Mc CANN and RETTORI, 1988). However, it was demonstrated that GABA has a direct effect on gonadotrophins release at the pituitary level involving GABA-A receptors (VIRMANI et al., 1990).

On the other hand, in mammals, GABA represents a major target of estradiol. Indeed, autoradiographic studies showed that a large number of GABA neurons are estrogen receptive neurons (FLUGGE et al., 1986). Furthermore, recent immunohistochemical works in mammals showed the expression of estradiol receptors in hypothalamic GABA neurons (HERBISON et al., 1993 ; Mc CARTHY et al., 1995). These data, suggesting that such neurons could mediate the effects of estradiol on GnRH secretion, are reintorced by the existence of synaptic contacts between GABAergic terminals and $\mathrm{LH}-\mathrm{RH}$ neurons (LERANTH et al., 1985).

In fish, less information is available about the neuroendocrine actions of GABA on gonadotrophin secretion. However, a role for GABA on GTH2 secretion was clearly demonstrated in goldfish. Indeed, intraperitoneal or intracerebroventricular injections of GABA or GABA-transaminase inhibitors stimulate GTH2 release (KAH et al., 1992 ; TRUDEAU et al., 1993a). Since a direct action on GTH cell has not been demonstrated in vitro, it has been postulated that the stimulatory actions of GABA on GTH2 release are mediated via GnRH and/or dopaminergic systems. The stimulatory effects of GABA on GTH2 release in goldfish result from both increased $G n R H$ release and decreased dopaminergic activity (TRUDEAU et al., 1993a). In addition, several in vivo experiments have shown that GABA stimulates GTH2 secretion in fish at early stages of gonadal development but was ineffective in mature or sexually regressed goldfish, suggesting that the stimulating effects of GABA on GTH2 levels depend on the steroid environment (KAH et al., 1992). According to these data, estradiol decreases the GABA-stimulated GTH2 release (KAH et al., 1992 ; TRUDEAU et al., 1993b). All these results confirm that GABA neurons constitute potential target for estradiol and would be involved in the steroid feedback on GTH secretion.

GABA levels in the central nervous system depend mainly on the activity of the glutamic acid decarboxylase (GAD), the enzyme synthesizing GABA. In mammals, two GADs are expressed in GABA neurons differing in their molecular weight (67 kD and $65 \mathrm{kD})$, their subcellular localization and their affinity for the co-factor pyridoxal-5'phosphate (PLP) necessary for enzyme activation (MARTIN et al., 1992). Despite these differences, both GADs synthesize GABA (ERLANDER et al., 1991 ; KAUFMAN et al., 1991). Hence, in order to know the distribution of GABA neurons in trout forebrain, we studied the detailed distribution of GAD65 mRNA-expressing neurons in the forebrain of the trout detected by means of non radioactive in situ hybridization using a digoxigenin (DIG)-labelled riboprobe.

Our study showed that GAD-expressing neurons were detected in the forebrain, from the olfactory bulbs to the mediobasal hypothalamus. However, we focused our attention on the possible neuroendocrine role of GABAergic neurons in the regulation of gonadotropin secretion. The very high density of GAD mRNA-expressing cells in the preoptic region and in the mediobasal hypothalamus strongly suggests its implication in the control of the pituitary function since in fish, including trout (ANGLADE, 1994), both regions are hypophysiotropic (Figure A, 1-6).

In addition, GABA neurons appear to be likely target of estradiol since their distribution in preoptic region and hypothalamus largely corresponds to the distribution of rtER-expressing cells suggesting that at least a part of them would express estradiol receptors. Our hypothesis is reinforced by colocalization studies in mammals showing that a large proportion of GABA neurons of the preoptic region and the basal hypothalamus 


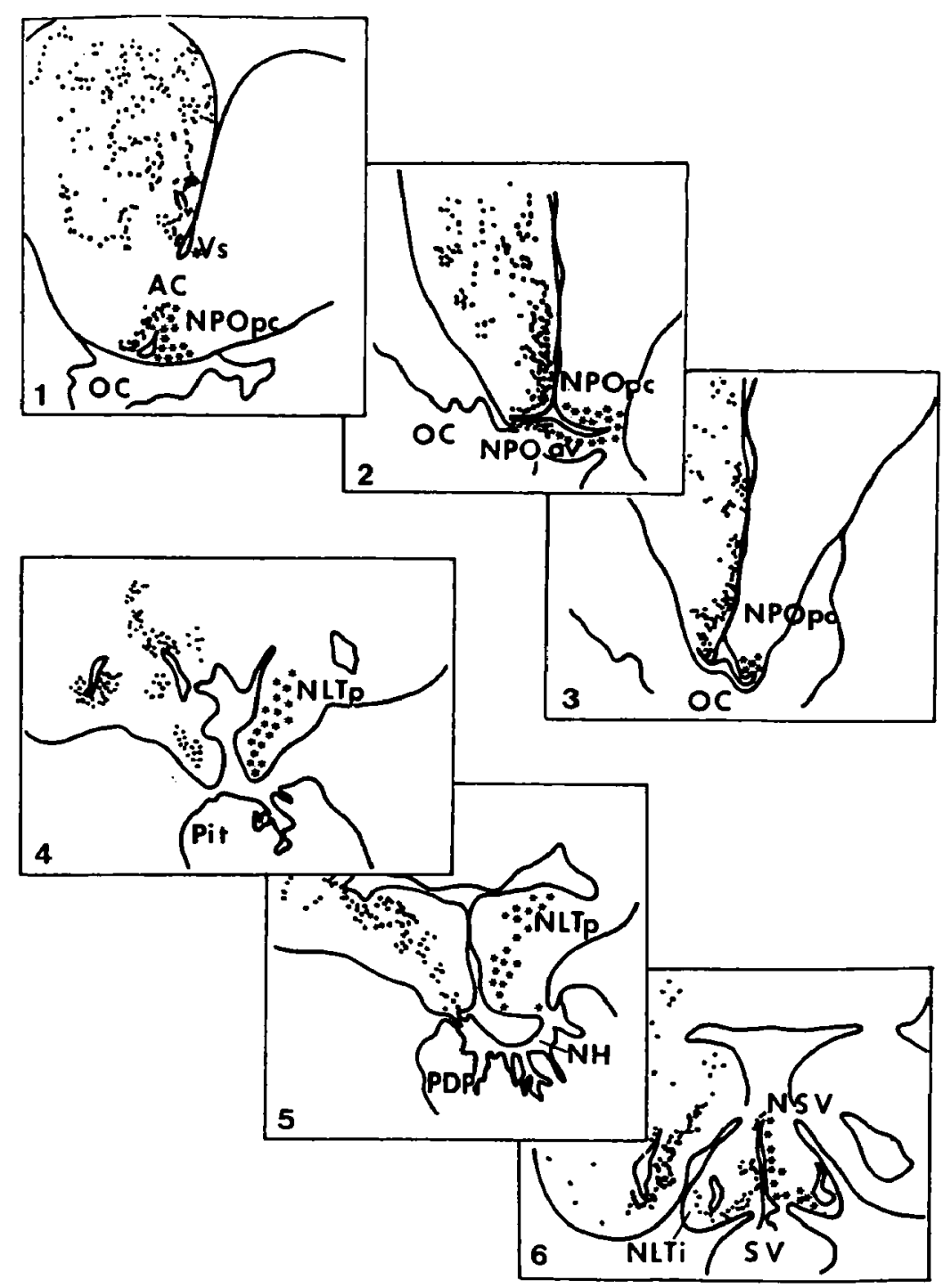

Figure A (1-6)

Representative transverse sections illustrating the comparative distribution of GAD mRNA-expressing cells (black circles) and estrogen receptor expressing cells (black stars) in the preoptic region and in the mediobasal hypothalamus of the rainbow trout. AC : anterior commissure ; NH : neurohypophysis ; NLTp : nucleus lateralis tuberis pars posterior ; NLTi : nucleus lateralis tuberis pars inferioris ; NPOav : nucleus preopticus pars anteroventralis ; NPOpc : nucleus preopticus pars parvicellularis ; NSV : nucleus saccus vasculosus ; OC : optic chiasma ; pit : pituitary gland ; PDP : pars distalis proximale ; sv : saccus vasculosus ; Vs : area ventralis telencephali pars supracommissuralis.

Figure A (1-6)

Représentations transversales schématiques illustrant la distribution comparée des cellules exprimant l'ARNm de la GAD (ronds noirs) et les cellules exprimant les récepteurs de l'oestradiol (étoiles noires).

AC : commissure antérieure ; NH : neurohypophyse ; NLTp : nucleus lateralis tuberis pars posterior ; NLTi : nucleus lateralis tuberis pars inferioris ; NPOav : nucleus preopticus pars anteroventralis ; NPOpc : nucleus preopticus pars parvicellularis ; NSV : nucleus saccus vasculosus ; OC : chiasma optique ; pit : hypophyse ; PDP : pars distalis proximale ; sv : saccus vasculosus ; Vs : area ventralis telencephali pars supracommissuralis. 
expresses estradiol receptors (HERBISON et al., 1993 ; THIND and GOLDSMITH, 1997). At this stage we can only speculate but in agreement with this hypothesis, recent data obtained in rainbow trout suggest that GABA may participate in the regulation of GTH2 secretion (MAÑANOS et al., unpublished data). These data suggest that GABA neurons would mediate the estrogenic feedback on GTH2 secretion in rainbow trout.

As mentioned above, GnRH neurons do not seem to be direct target of estradiol. However, numerous studies in fish showed that $\mathrm{GnRH}$ neuron activity is regulated by estradiol. GABA neurons, at least in the preoptic region, can represent the missing link between estradiol and GnRH neurons located in this region (BAILHACHE et al., 1994). Such interactions between GABAergic and $\mathrm{GnRH}$ neurons exist in mammals in which synaptic connections between GABAergic terminals and $\mathrm{GnRH}$ neurons were visualized (LERANTH et al., 1985). The high density of GABA neurons in this region offers also opportunities of interaction with dopaminergic and the other neuroendocrine systems located in this region (KAH et al., 1993). The dense GABAergic innervation (MARTINOLI et al., 1990 ; MEDINA et al., 1994) of the preoptic region and mediobasal hypothalamus in fish suggests the possible role of relay of GABA neurons. All these observations support the hypothesis of an indirect GABAergic control on GTH (mainly GTH2) secretion. However, a direct GABAergic control is not excluded.

\section{CONCLUSION}

In summary, GABA neurons represent probably an important factor involved in the estrogenic feedback on GTH2 secretion since they are located in a strategic position in the brain : they may likely integrate estrogenic information and transmit this message to the gonadotroph cells either directly or indirectly via the regulation of other neuroendocrine systems at the central level.

\section{REFERENCES}

ANGLADE I., ZANDBERGEN A.M., KAH O., 1993. Origin of the pituitary innervation in the goldfish. Cell. Tissue Res., 273, 345- 355.

ANGLADE I., 1994. Morphofunctional study of the neuroendocrine systems involved in the control of the gonadotrophic function in bony fish. Ph. D. Thesis, University of Bordeaux I, $N^{\circ} 1192,1-122$.

ANGLADE I., PAKDEL F., BAILHACHE T., PETIT F., VALOTAIRE Y., JÉGO P., KAH O., 1994. Distribution of estrogen receptor-immunoreactive cells in the brain of the rainbow trout (Oncorhynchus mykiss). J. Neuroendocrinol., 6, 573-583.

BAILHACHE T., ARAZAM A., KLUNGLAND H., ALESTRÖM P., BRETON B., JEGO P., 1994. Localization of salmon GnRH mRNA and peptide in the brain of Atlantic saimon and rainbow trout. J. Comp. Neurol., 347, 444-454.

BEATO M., HERRLICH P., SCHÜTZ G., 1995. Steroid hormone receptors : many actors in search of a plot. Cell., 83, 851-857.

DONOSO A.O., SELTZER A.M., NAVARRO C.E., CABRERA R.J., LOPEZ F.J., NEGROVILAR A., 1994. Regulation of luteinizing hormone-releasing hormone and luteinizing hormone secretion by hypothalamic amino acids. Brazillian J. Med. Biol. Res., 27, 921-932.

DUFOUR S., FONTAINE Y.A., KEDERLHUÉ B., 1985. Increase in brain and pituitary radioimmunoassayable Gonadotropin-Releasing Hormone $(\mathrm{GnRH})$ in the European silver eel treated with sexual steroid or human chorionic gonadotropin. Neuropeptide, 6, 495-502, (1985; 1993). 
DUFOUR S., MONTERO M., LE BELLE N., BASSOMPIERRE M., KING J.A., MILLAR R.P., PETER R.E., FONTAINE Y.A., 1993. Differential distribution and response to experimental sexual manipulation of two forms of brain gonadotrophin-releasing hormone in the European eel, Anguilla anguilla. Fish Physiol. Biochem., 11, 99-106.

ERLANDER M.G., TILLKARATNE N.J.K., FELDBLUM S., PATEL N., TOBIN A.J., 1991. Two genes encode distinct glutamate decarboxylases. Neuron., 7, 91-100.

FLUGGE G., OERTEL W.H., WUTTKE W., 1986. Evidence for estrogen receptive GABAergic neurons ion the preoptic/anterior hypothalamic area of the rat brain. Neuroendocrinology, 43, 1-5.

HERBISON A.E., THEODOSIS D., 1992. Localization of estrogen receptors in preoptic neurons containing neurotensin but not tyrosine hydroxylase, cholecystokinin or luteinizing hormone-releasing hormone in the male and female rat. Neuroscience, 50, 283-298.

HERBISON A.E., ROBINSON J.E., SKINNER D.C., 1993. Distribution of estrogen receptorimmunoreactive cells in the preoptic area of the Ewe : co-localization with glutamic acid decarboxylase but not luteinizing hormone-releasing hormone. Neuroendocrinology, $57,751-759$.

JOHNSTON S.A., MALER L., 1992. Anatomical organization of the hypophysiotropic systems in the electric fish, Apteronotus leptorhynchus. J. Comp. Neurol., 317, 421-437.

KAH O., TRUDEAU V.L., SLOLEY B.D., CHANG J.P., DUBOURG P., YU K.L., PETER R.E., 1992. Influence of GABA on gonadotropin release in the goldfish. Neuroendocrinology, 55, 396-404.

KAH O., ANGLADE I., LEPRÊTRE E., DUBOURG P., DE MONBRISON D., 1993. The reproductive brain in fish. Fish Physiol. Biochem., 11, 85-98.

KAUFMAN D.L., HOUSER C.R., TOBIN A.J., 1991. Two forms of the gamma-aminobutyric acid synthetic enzyme glutamate decarboxylase have distinct intraneuronal distributions and cofactor interactions. J. Neurochem., 56 (2), 720-723.

KIM Y.S., STUMPF W.E., SAR M., 1978. Topography of estrogen target cells in the forebrain of the goldfish, Carassius auratus. J. Comp. Neurol., 182, 611-620.

KLUNGLAND H., ANDERSEN O., KISEN P., ALESTRÖM P., TORA L., 1993. Estrogen receptor binds to the salmon $\mathrm{GnRH}$ gene in a region with long palindromic sequences. Mol. Cell. Endocrinol., 95, 147-154.

LERANTH C.S., MAC LUSKY N.J., SAKAMOTO H., SHANABROUGH M., NAFTOLIN F., 1985. Glutamic acid decarboxylase-containing axons synapse on $\mathrm{LH}-\mathrm{RH}$ neurons in the rat medial preoptic area. Neuroendocrinology, 40, 536-539.

LINARD B., BENNANI S., JEGO P., SALIGAUT C., 1996a. Tyrosine hydroxylase activity and dopamine turn-over of rainbow trout (Oncorhynchus mykiss) brain : special status of the hypothalamus. Fish Physiol. Biochem., 15, 41-48.

LINARD B., ANGLADE I., NAVAS J.M., CORIO M., JÉGO P., SALIGAUT C., KAH O., 1996b. Estrogen receptors are expressed in a subset of tyrosine hydroxylase positive neurons of the anterior preoptic region in the rainbow trout. Neuroendocrinology, 63 , 156-165.

MARTIN D.L., MARTIN S.B., WU S.J., ESPINA N., 1992. Regulatory properties of brain glutamate decarboxylase (GAD) : the apoenzyme of GAD is present principally as the smaller of two molecular forms of GAD in brain. J. Neurosci., 11, 2725-2731.

MARTINOLI M.G., DUBOURG P., GEFFARD M., CALAS A., KAH O., 1990. Distribution of GABA-immunoreactive neurons in the forebrain of the goldfish. Cell. Tissue Res., 260, 77-84.

MC CANN S.M., RETTORI V., 1988. The role of gamma aminobutyric acid in the control of anterior pituitary hormone secretion. In GABA and benzodiazepine receptors, Squires R.F. ed., CRC Press, Boca Raton, 123-134. 
MC CARTHY M.M., KAUFMAN L.C., BROOKS P.J., PFAFF D.W., SCHWARTZ-GIBLIN S., 1995. Estrogen modulation of mRNA levels for the two forms of glutamic acid decarboxylase (GAD) in female rat brain. J. Comp. Neurol., 360, 685-697.

MEDINA M., REPERANT J., DUFOUR S., WARD R., LE BELLE N., MICELI D., 1994. The distribution of GABA-immunoreactive neurons in the brain of the silver eel (Anguilla anguilla L.). Anat. Embryol. Anat., 189, 25-39.

MONTERO M., LE BELLE N., KING J.A., MILLAR R.P., DUFOUR S., 1995. Differential regulation of the two forms of gonadotropin-releasing hormone $(\mathrm{mGnRH}$ and $\mathrm{cGnRH}-1 \mathrm{l}$ ) by sex stertoids in the European female silver eel. (Anguilla anguilla). Neuroendocrinology, 61(5), 525-535.

NAVAS J.M., ANGLADE I., BAILHACHE T., PAKDEL F., BRETON B., JÉGO P., KAH O., 1995. Do gonadotrophin-releasing hormone neurons express estrogen receptors in the rainbow trout? A double immunohistochemical study. J. Comp. Neurol., 363, 461-474.

PAKDEL F., LE GAC F., LE GOFF P., VALOTAIRE Y., 1990. Full length sequence and in vitro expression of rainbow trout estrogen receptor cDNA. Mol. Cell. Endocrinol., 71, 195-204.

PAKDEL F., PETIT F., ANGLADE I., KAH O., DELAUNAY F., BAILHACHE T., VALOTAIRE Y., 1994. Overexpression of rainbow trout estrogen receptor domains in E. Coli : characterization and utilization in the production of antibodies for immunoblotting and immunocytochemistry. Mol. Cell. Endocrinol., 96, 177-182.

SALBERT G., BONNEC G., LE GOFF P., BOUJARD D., VALOTAIRE Y., JÉGO P., 1991. Localization of the estradiol mRNA in the forebrain of the rainbow trout. Mol. Cell. Endocrinol., 78, 173-180.

SALIGAUT C., GARNIER D., BENNANI S., SALBERT G., BAILHACHE T., JEGO P., 1992. Effects of oestradiol on brain aminergic turn-over of the female rainbow trout (Oncorhynchus mykiss) at the beginning of the vitellogenesis. Gen. Comp. Endocrinol., 88, 209-216.

SHIVERS B.D., HARLAN R.E., MORRELL J.I., PFAFF D.W., 1983. Absence of oestradiol concentration in cell nuclei of $\mathrm{LH}-\mathrm{RH}$ immunoreactive neurones. Nature, 304 , 345-347.

THIND K.K., GOLDSMITH P.C., 1997. Expression of estrogen receptors in glutamate and GABA neurons of the pubertal female monkey hypothalamus. Neuroendocrinology, 65, 314-324.

TRUDEAU V.L., SLOLEY B.D., WONG A.O.L., PETER R.E., 1991. Mechanisms of sex steroids negative and positive feedback control of gonadotropin release (GTH) secretion in teleosts. In Reproductive Physiology of Fish, Scott A.P., Sumpter J.P., Kime D.E., Rolfe M.S. (eds), Univ. of East Anglia Printing Unit, Sheffield, UK, 224-226.

TRUDEAU V.L., SLOLEY B.D., PETER R.E., 1993a. GABA stimulation of gonadotropin-II release in goldfish, involvement of GABA-A receptors, dopamine, and sex steroids. American Journal of Physiology, 265, R348-R355.

TRUDEAU V.L., SLOLEY B.D., PETER R.E., 1993b. Testosterone enhances GABA and taurine but not N-Methyl-D,L-Aspartate stimulation of gonadotropin secretion in the goldfish : possible sex steroid feedback mechanisms. J. Neuroendocrinol., 5, 129-136.

TRUDEAU V.L., PETER R.E., 1995. Functional interactions between neuroendocrine systems regulating GTH-II release. In Reproductive Physiology of Fish, edited by Goetz F.W. and Thomas P., Fish Symp. 95, Austin, USA, 44-48.

TRUDEAU V.L., 1997. Neuroendocrine regulation of gonadotrophin-II release and gonadal growth in the goldfish, Carassius auratus. Reviews of Reprod., 2, 55-68.

VIRMANI M.A., STOJILKOVIC S.S., CATT K.J., 1990. Stimulation of Luteinizing-Hormone release by $y$-aminobutiric acid (GABA) agonists : mediation by GABA-A type receptors and activation of chloride and voltage sensitive calcium channels. Endocrinology, 126 (5), 2499-2505. 